\title{
Correlation between gall bladder fasting volume and postprandial emptying in patients with gall stones and healthy controls
}

\author{
J Pauletzki, M Cicala, J Holl, T Sauerbruch, A Schafmayer, G Paumgartner
}

\begin{abstract}
To evaluate whether the extent of postprandial gall bladder emptying is correlated with gall bladder fasting volume, gall bladder motility was studied in 56 patients with cholesterol gall stone and 19 control patients. Gall bladder volumes were determined sonographically, while cholecystokinin plasma values were measured radioimmunologically. Twenty three per cent of gall stone patients were classified as pathological contractors (residual fraction $>$ mean +2 SD of controls) and $77 \%$ as normal contractors. Normal but not pathological contractor patients exhibited larger gall bladder fasting volumes (mean (SEM)) (24.7 $(1.7) \mathrm{ml})$ than controls $(15.3(1.2) \mathrm{ml}, \mathrm{p}<0.001)$. In normal contractor patients and controls fasting volume was closely related with ejection volume $(r=0.97, p<0.001)$ and residual volume $(r=0.80, p<0.001)$. Although ejection volume was enlarged in normal contractor patients it did not compensate the increase in fasting volume. Thus, residual volumes were considerably increased not only in pathological contractors $(12.7(2.5) \mathrm{ml}, \mathrm{p}<0.001)$ but also in normal contractor patients $(7.0(0.5) v 4.6(0.6)$ $\mathrm{ml}, \mathrm{p}<0.001)$. Postprandial cholecystokinin secretion did not differ between patients and controls. It is concluded, that in normal contractor patients gall bladder fasting volume is closely correlated with ejection and residual volume. Thus, fasting volume may be an essential factor affecting postprandial gall bladder emptying. Large fasting volumes in cholesterol gall stone disease could thereby contribute to bile retention, which facilitates gall stone growth.
\end{abstract}

(Gut 1993; 34: 1443-1447)

Department of Medicine II, Ludwig-MaximiliansUniversity, Munich J Pauletzki

M Cicala

J Holl

T Sauerbruch

P Paumgartner

and Department of Surgery, Georg-AugustSurgery, Georg-August A Schafmayer

Correspondence to:

Correspondence to:
Dr J Pauletzki, Dept of

Mredicine II, Klinikum

Mrosshadern, University of

Grosshadern, University of
Munich, Marchioninistrasse

15 , D-8000 Munich 70,

Germany.

Accepted for publication

9 February 1993
The importance of gall bladder motility in the debate on the various causes of gall stones in humans is still to be determined. ' Convincing evidence exists that impaired gall bladder motor function is an important determinant of gall stone formation during longterm parenteral nutrition, ${ }^{2}$ pregnancy, ${ }^{3}$ somatostatinoma, ${ }^{4}$ and somatostatin treatment. ${ }^{5}$ Applying different techniques in small or highly selected groups of gall stone patients, different investigators reported decreased, ${ }^{6-14}$ normal, ${ }^{15-17}$ or even increased ${ }^{18}$ gall bladder emptying by comparison with healthy controls. Moreover, it has been postulated that two distinct subgroups of gall stone patients can be identified with regard to gall bladder emptying (normal contractors, pathological contractors), who may differ with respect to gall stone pathogenesis. ${ }^{141920}$ In addition, recent reports suggest that gall stone patients may be characterised by enlarged fasting volumes. ${ }^{911} 19$

We therefore speculated that gall bladder fasting volume might be an essential factor in the regulation of gall bladder motility. To evaluate whether gall bladder motor function is correlated with gall bladder fasting volume we studied the relation between fasting volume and postprandial emptying as well as postprandial cholecystokinin (CCK) secretion in a large group of cholesterol gall stone patients and healthy subjects. Gall stone patients were divided into normal and pathological contractor patients to show different aspects of changed gall bladder motility in these groups compared with controls.

\section{Patients and methods}

\section{PATIENTS}

Gall bladder motility was assessed in 56 patients with radiolucent gall stones and 19 healthy controls. Both groups did not differ with regard to clinical characteristics (Table I). All gall stone patients were evaluated in our outpatient clinic for indications of gall stone treatment. Twenty three patients $(41 \%)$ suffered from biliary pain, while the other 33 patients $(59 \%)$ had no biliary symptoms. No patient presented with clinical or laboratory signs of biliary complications. To allow a valid motility investigation to be done the patency of the cystic duct was proved by opacification of the gall bladder on oral cholecystogram. Total stone volume $\left(\Sigma\left[4 \pi \mathrm{r}_{\mathrm{i}}^{3}\right] / 3\right.$ with $r_{i}=$ half of largest diameter of each stone on ultrasound) was 19 (2)\% of gall bladder fasting volume. In all subjects the gall bladder wall and common bile duct was normal when examined by ultrasound. No patient had any history of disease or operations known to affect gall bladder motility or took any drugs. Informed consent was obtained from all patients and healthy subjects and the study protocol was approved by the ethics committee of the Medical Faculty of the University of Munich.

\section{GALL BLADDER EMPTYING}

Gall bladder volumes were determined sonographically (curved array transducer $3.5 \mathrm{MHz}$, CS 9000, Picker International, Germany) and calculated according to the sum of cylinders method. ${ }^{21}$ Intraindividual variation of gall bladder volume measurements was less than $5 \%$. Gall stone patients and controls were studied between 8 am and $10 \mathrm{am}$ after an overnight fast. Fasting volumes were determined at times -15 , 
TABLE I Characteristics of gall stone patients and controls

\begin{tabular}{lllll}
\hline & \multicolumn{2}{l}{ Gall stone patients } & \\
\cline { 2 - 4 } & $\begin{array}{l}\text { Normal } \\
\text { contractors }\end{array}$ & $\begin{array}{l}\text { Pathological } \\
\text { contractors }\end{array}$ & All & Controls \\
\hline No & 43 & 13 & 56 & 19 \\
Sex $(\mathrm{f} / \mathrm{m})(\%)$ & $79 / 21$ & $69 / 31$ & $77 / 23$ & $58 / 42$ \\
Age $(\mathrm{y})$ & $46(2)$ & $42(4)$ & $46(2)$ & $41(3)$ \\
BMI $\left(\mathrm{kg} / \mathrm{m}^{2}\right)$ & $25 \cdot 4(0 \cdot 6)$ & $23 \cdot 2(0 \cdot 9)$ & $25 \cdot 0(0 \cdot 5)$ & $23 \cdot 1(0 \cdot 6)$ \\
BSA $\left(\mathrm{m}^{2}\right)$ & $1 \cdot 77(0 \cdot 03)$ & $1 \cdot 72(0 \cdot 05)$ & $1 \cdot 76(0 \cdot 02)$ & $1 \cdot 78(0 \cdot 04)$ \\
Stone number & $1 \cdot 7(0 \cdot 2)$ & $1 \cdot 6(0 \cdot 3)$ & $1 \cdot 7(0 \cdot 2)$ & \\
Size of largest stone $(\mathrm{mm})$ & $17(1)$ & $19(1)$ & $17(1)$ & \\
Biliary pain (\% patients) & 47 & 23 & 41 & \\
\hline
\end{tabular}

BMI: body mass index, BSA: body surface area. Clinical characteristics did not differ significantly between groups. Mean (SEM).
$-10,-5$, and 0 minutes before the test meal. Postprandial gall bladder images were recorded 30,60 , and 90 minutes after a standard liquid test meal (473 kcal, $10 \mathrm{~g}$ fat, $35 \mathrm{~g}$ protein, $55 \mathrm{~g}$ carbohydrates). No patient experienced biliary pain during the motility study.

Results are expressed as fasting volumes (FV) $(\mathrm{ml})$ at times $-15(\mathrm{FV}-15),-10(\mathrm{FV}-10),-5$ $(\mathrm{FV}-5)$ and $0(\mathrm{FV})$ minutes before the test meal was given, residual volume $(\mathrm{RV})(\mathrm{ml})$ defined as the smallest postprandial volume, residual fraction $(\mathrm{RF}=\mathrm{RV} / \mathrm{FV})(\%)$, total ejection volume $(\mathrm{EV}=\mathrm{FV}-\mathrm{RV})(\mathrm{ml})$, and ejection volume 30 minutes after the test meal (EV30) (ml). According to Pomeranz and Shaffer ${ }^{14}$ pathological contractor patients were defined by a residual fraction exceeding the mean of healthy controls $+2 \mathrm{SD}$.

\section{CCK MEASUREMENTS}

Heparinised blood samples were drawn on ice for CCK plasma determinations before and 30, 60, and 90 minutes after the liquid test meal. Aprotinin (500 E/ml) (Trasylol, Bayer, Germany) was added immediately. After centrifugation (3000 $\mathrm{g}$ for 10 minutes) plasma was frozen at $-30^{\circ} \mathrm{C}$ until radioimmunological determination of CCK. Plasma CCK concentrations were measured with a specific radioimmunoassay
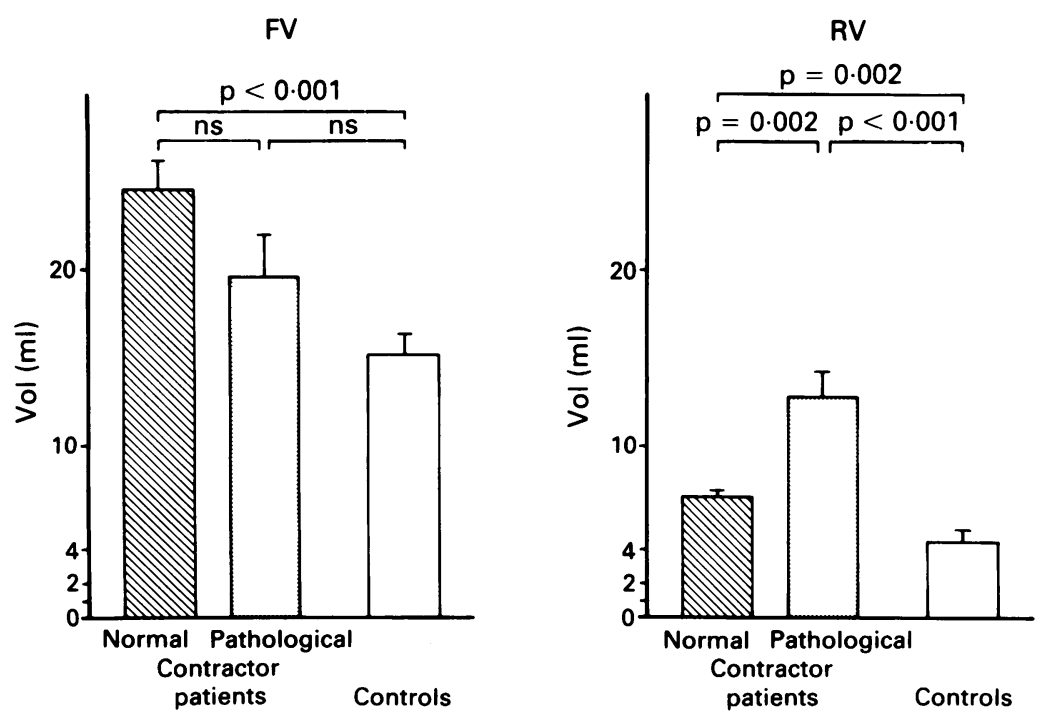

Figure 1: Fasting volume $(F V)$ and residual volume $(R V)$ of the gall bladder after a standard liquid test meal in gall stone patients (normal $(n=43)$ and pathological $(n=13)$ contractor patients) and controls $(n=19)$. Mean $(S E M)$. as described previously. ${ }^{22}$ Antibody G120 was directed against the sulfated tyrosyl group of CCK. Cross reaction with sulfated gastrin was less than $2 \%$. Synthetic $\mathrm{CCK}_{8}$ was used as standard (Squibb, Germany), ${ }^{125} \mathrm{~J}$-Bolton-Hunter labelled synthetic $\mathrm{CCK}_{8}$ as tracer.

Results are expressed as basal plasma values $\left(\mathrm{CCK}_{\mathrm{bas}}\right)(\mathrm{pM})$, maximal CCK levels $\left(\mathrm{CCK}_{\max }\right)$ $(\mathrm{pM})$, and the integrated CCK secretion given by the area under the $\mathrm{CCK}-\mathrm{CCK}_{\mathrm{bas}} /$ time curve during 90 minutes postprandially. (CCK-AUC) (pMx90 min).

\section{STATISTICS}

Data were analysed by $\chi^{2}$ test and one way or two way analysis of variance (ANOVA) as appropriate. When multiple comparisons were performed a Newman-Keuls procedure was subsequently applied. Correlations were evaluated by linear regression (Pearson's correlation coefficient). Results were given as mean (SEM). Differences between means were considered significant at the $p<0.05$ value.

\section{Results}

Gall stone patients were divided into two groups according to the reference range of the postprandial residual fraction of the gall bladder obtained from healthy controls (mean (2 SD): 30 (18\%): 43 patients $(77 \%)$ were normal contractors and 13 patients $(23 \%)$ pathological contractors. All gall bladder motility parameters did not show an obvious bimodal distribution but a gradual transition from normal to pathological values.

Fasting volumes of the gall bladder obtained at times $-15,-10,-5$, and 0 minutes before the test meal did not vary significantly in gall stone patients $(23.7(1.5) \mathrm{ml}, 23.8(1.5) \mathrm{ml}, 23.4(1.4)$ $\mathrm{ml}, 23.6(1.5) \mathrm{ml})$ or in controls $(15.2(1.2) \mathrm{ml}$, $16.0(1 \cdot 5) \mathrm{ml}, 15 \cdot 4(1 \cdot 3) \mathrm{ml}, 15 \cdot 3(1 \cdot 2) \mathrm{ml})$. The larger fasting volume, which was seen in gall stone patients, was specifically characteristic of gall stone patients classified as normal contractor patients (Fig 1). Fasting volume correlated closely with ejection volume in normal contractor patients $(\mathrm{r}=0.97, \mathrm{p}<0.001)$ and controls $(\mathrm{r}=.97, \mathrm{p}<0.001)$. Also, for both groups combined, the same close correlation was obtained between fasting volume and ejection volume $(\mathrm{r}=0.97, \mathrm{p}<0.001)$ (Fig 2). Although the ejection phase lasted longer in normal contractor patients (Fig 3), a similar relation existed already between fasting volume and 30 minute ejection volume $(\mathrm{r}=0.92, \mathrm{p}<0.001)$. Combining normal contractor patients and controls fasting volume was also directly related to residual volume $(\mathrm{r}=0.80, \mathrm{p}<0.001)$ (Fig 4). In gall stone patients fasting volume did not depend on any parameter of body size, whereas in controls fasting volume was slightly related to body weight $(r=0.64, p<0.01)$ and body surface area $(r=0.56, p<0.01)$. Healthy controls showed rapid gall bladder emptying within the first 30 minutes postprandially followed by subsequent refilling. By contrast, normal contractor patients showed a prolonged emptying phase and a later onset of refilling (Fig 3). Normal contractor patients exhibited a total ejection volume $70 \%$ 


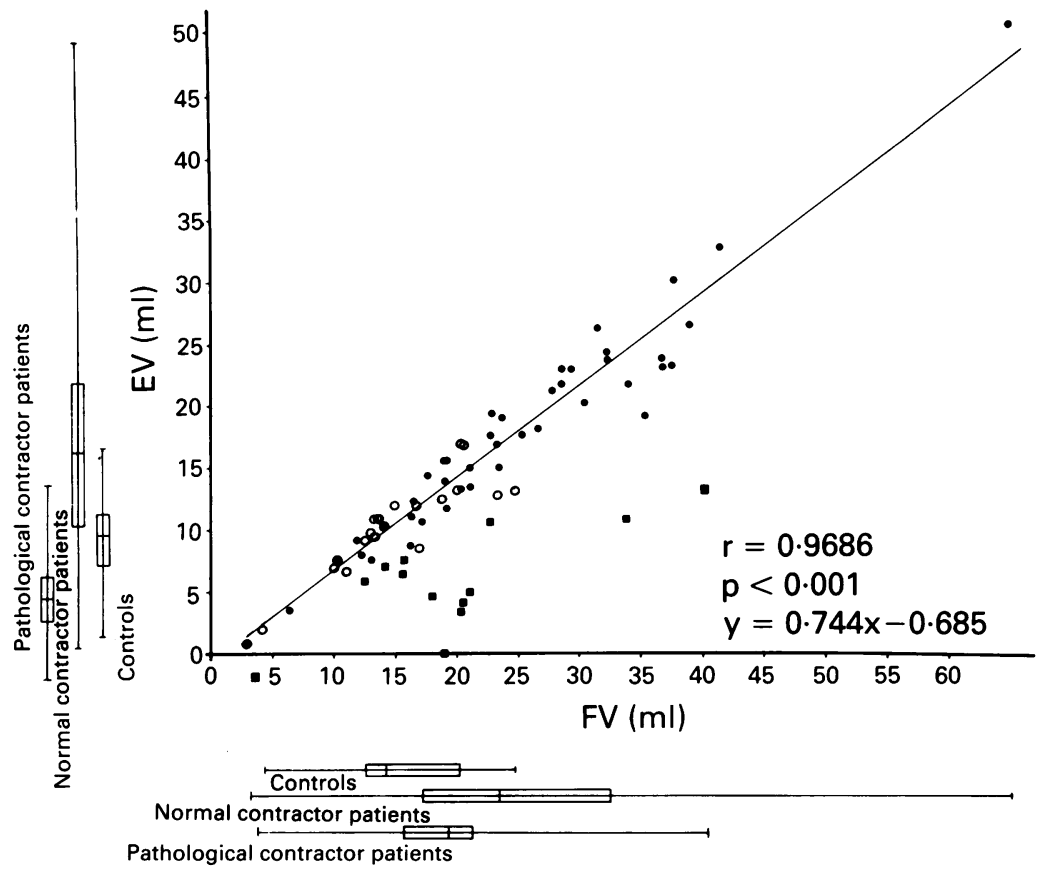

Figure 2: Correlation of fasting volume (FV) of the gall bladder and postprandial ejection volume $(E V)$ in normal contractor gall stone patients $(\mathbf{)}$ ) and controls $(\mathrm{O})$. Pathological contractor patients shown by $(\mathbf{\square})$.

Gallstone patients

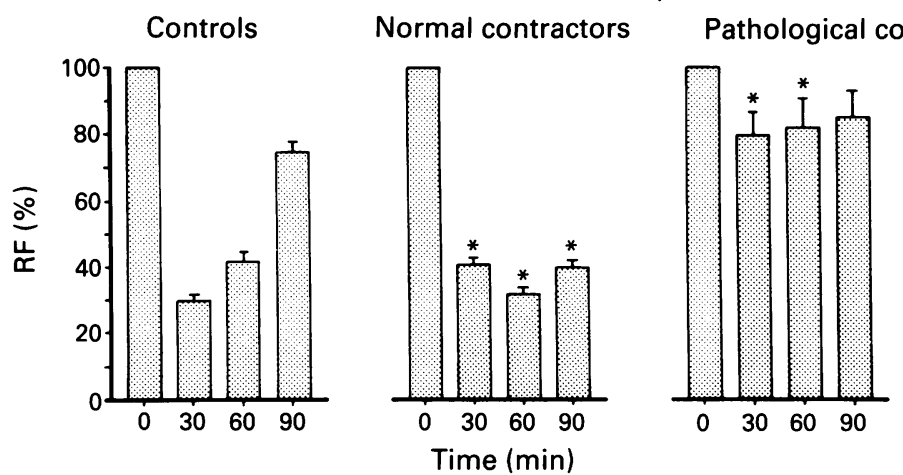

Figure 3: Residual fraction $(R F)$ of the gall bladder before and 30,60, and 90 minutes after a standard liquid test meal in gall stone patients (normal $(n=43)$ and pathological $(n=13)$ contractor patients) and controls $(n=19)$. Mean $(S E M),{ }^{\star} p<0.05$ with controls.

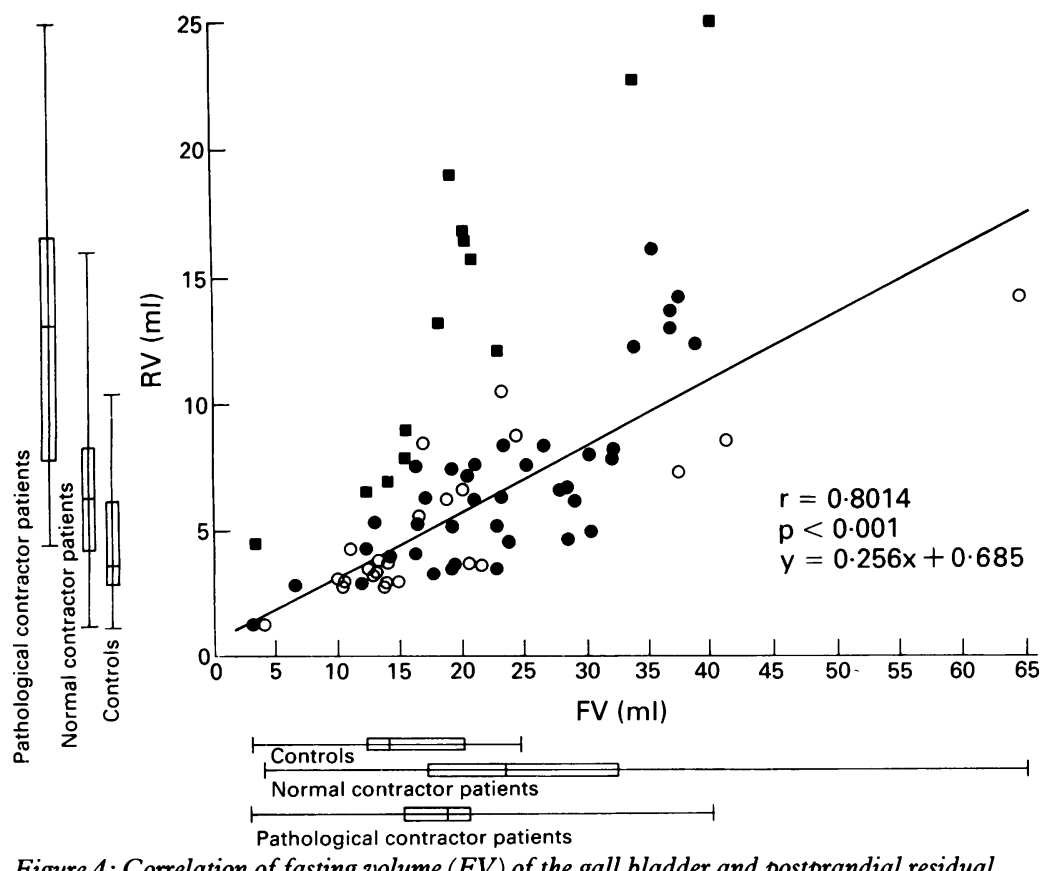

Figure 4: Correlation of fasting volume (FV) of the gall bladder and postprandial residual volume $(R V)$ in normal contractor gall stone patients $(\mathbf{O})$ and controls $(\mathrm{O})$. Pathological contractor patients shown by $(\mathbb{\square})$. larger than in controls. Thirty minute ejection volumes were significantly increased in normal contractor patients compared with controls (Table II). Furthermore, gall stone patients were characterised by a larger postprandial residual volume (Table II). In normal contractor patients the residual volume was increased by nearly $50 \%$ compared with controls, whereas pathological contractors showed even larger residual volumes (Fig 1).

Normal and pathological contractor patients as well as controls did not differ with regard to either basal or maximal postprandial CCK plasma values or integrated CCK secretion (Table III)

Although $47 \%$ of normal contractor patients but only $23 \%$ of pathological contractor patients reported episodes of biliary pain, this trend did not reach statistical significance (Table I).

\section{Discussion}

This study shows a close correlation of gall bladder fasting volume with postprandial ejection and residual volume in healthy subjects and gall stone patients with normal gall bladder contractility. Thus, fasting volume may be an essential factor of gall bladder motility affecting postprandial emptying.

Normal contractor gall stone patients exhibited an appreciably increased fasting volume of the gall bladder, which was independent of stone volume. Only normal contractor patients, however, showed an enlarged mean fasting volume whereas pathological contractor patients did not. As it has been shown that in healthy subjects fasting volume is slightly related to body surface area and weight, ${ }^{23}$ we carefully matched patients and controls for clinical characteristics (Table I). Furthermore, fasting gall bladder volume can vary up to $20 \%$ because of a small short term contraction and subsequent refilling associated with late phase II of the gastroduodenal migrating motor complex. ${ }^{24} \mathrm{As}$, in our study, fasting volumes did not differ throughout a 15 minute period before the test meal was given, we assume that they were in a steady state at the start of the motility examination. Increased fasting volumes have been reported during pregnancy, ${ }^{3}$ after treatment with ursodeoxycholic acid, ${ }^{892526}$ chenodeoxycholic acid, ${ }^{26}$ somatostatin, ${ }^{24}$ CCK antagonists, ${ }^{27}$ neurotensin, ${ }^{28}$ atropine, ${ }^{29}$ and after truncal vagotomy. ${ }^{30}$ Nevertheless, further studies are required to identify the mechanism of enlarged fasting volumes in gall stone patients.

In addition to other studies ${ }^{89111219}$ reporting increased postprandial residual volumes of the gall bladder in gall stone patients, we showed that not only pathological contractor patients but also normal contractor patients exhibit distinctly larger residual volumes than controls. This retention of bile in the gall bladder in most gall stone patients may facilitate the nucleation of cholesterol crystals and stone growth. Whereas increased residual volumes may be the final consequence of changed gall bladder motility in cholesterol gall stone disease the results of our study point to different underlying mechanisms in various subgroups of patients. In pathological contractor patients without cholecystitis 
TABLE II Gall bladder emptying after a standard liquid test meal in gall stone patients and controls

\begin{tabular}{|c|c|c|c|c|c|c|c|c|}
\hline & \multicolumn{3}{|c|}{ Gall stone patients } & \multirow{3}{*}{$\begin{array}{l}\text { Controls } \\
n=19 \\
(4)\end{array}$} & \multirow{2}{*}{\multicolumn{4}{|c|}{$p$ Values }} \\
\hline & \multirow{2}{*}{$\begin{array}{l}\text { Normal } \\
\text { contractors } \\
n=43 \\
(1)\end{array}$} & \multirow{2}{*}{$\begin{array}{l}\text { Pathological } \\
\text { contractors } \\
n=13 \\
(2)\end{array}$} & \multirow{2}{*}{$\begin{array}{l}\text { All } \\
n=56 \\
(3)\end{array}$} & & & & & \\
\hline & & & & & $(1-2)$ & $(1-4)$ & $(2-4)$ & $(3-4)$ \\
\hline $\begin{array}{l}\mathrm{FV}(\mathrm{ml}) \\
\mathrm{RV}(\mathrm{ml}) \\
\mathrm{RF}(\%) \\
\mathrm{EV}(\mathrm{ml}) \\
\mathrm{EV}_{30}(\mathrm{ml})\end{array}$ & $\begin{array}{c}24.7(1.7) \\
7.0(0.5) \\
29(1) \\
17.7(1.3) \\
14.9(1.2)\end{array}$ & $\begin{array}{c}19 \cdot 6(2 \cdot 5) \\
12 \cdot 7(1 \cdot 5) \\
69(6) \\
6.9(1 \cdot 8) \\
4 \cdot 8(1 \cdot 2)\end{array}$ & $\begin{array}{c}23 \cdot 6(1 \cdot 5) \\
8 \cdot 3(0 \cdot 6) \\
38(3) \\
15 \cdot 2(1 \cdot 2) \\
12 \cdot 5(1 \cdot 1)\end{array}$ & $\begin{array}{l}15 \cdot 3(1 \cdot 2) \\
4 \cdot 6(0 \cdot 6) \\
30(2) \\
10 \cdot 7(0 \cdot 8) \\
10 \cdot 6(0 \cdot 8)\end{array}$ & $\begin{array}{l}\mathrm{NS} \\
\mathrm{p}=0.02 \\
\mathrm{p}<0.001 \\
\mathrm{p}<0.001 \\
\mathrm{p}<0.001\end{array}$ & $\begin{array}{l}\mathrm{p}<0.001 \\
\mathrm{p}=0.02 \\
\mathrm{NS} \\
\mathrm{p}=0.001 \\
\mathrm{p}=0.02\end{array}$ & $\begin{array}{l}\text { NS } \\
p<0.001 \\
p<0.001 \\
N S \\
p<0.001\end{array}$ & $\begin{array}{l}\mathrm{p}<0.001 \\
\mathrm{p}=0.002 \\
\mathrm{p}=0.03 \\
\mathrm{p}=0.01 \\
\mathrm{NS}\end{array}$ \\
\hline
\end{tabular}

$\mathrm{FV}=$ fasting volume, $\mathrm{RV}=$ residual volume, $\mathrm{RF}=$ residual fraction, $\mathrm{EV}=$ total ejection volume, $\mathrm{EV}_{30}=30$ minute ejection volume, $\mathrm{Mean}$ (SEM), NS= not significant.

impaired gall bladder emptying seems to be based on a functional defect of the gall bladder smooth muscle that is different from inflammation or fibrosis. ${ }^{31}$ On the other hand, in normal contractor patients enlarged residual volumes of the gall bladder are closely correlated with increased fasting volumes suggesting that expansion of the fasting volume may be an essentia event during the formation and growth of gall stones. Prospective studies of subjects with large gall bladder fasting volumes are required to identify this finding as a risk factor or early indicator of gall stone formation.

Specifically, the correlation between gall bladder fasting volume and 30 minutes ejection volume suggests a physiological mechanism by which the gall bladder can eject greater bile volumes as fasting volumes increase. Theoretically, the distension of the gall bladder wall may either change the sensitivity to CCK and neural stimulation or may improve muscular contraction in a way similar to the Starling mechanism of the heart. ${ }^{32}$ Such an analogous mechanism is particularly interesting, as smooth muscle cells differ in many aspects from heart or skeletal muscle..$^{33}$ In support of this hypothesis Ryan and Cohen $^{34}$ showed in the opossum, that the pressure increments induced by CCK were increased at larger gall bladder volumes. Moreover, guinea pig gall bladder smooth muscle showed a length dependency of isometric stress in response to acetylcholine stimulation in vitro. ${ }^{35}$ Our clinical data support the assumption of a comparable physiological characteristic in man. This mechanism, however, could not enhance ejection volume as much as it would be necessary to compensate for the increment in fasting volume. Thus, fasting volume also correlated directly with residual volume in normal contractors. As bile viscosity ${ }^{36}$ and sphincter of Oddi and common bile duct pressures ${ }^{37}$ do not differ between gall stone patients and controls an

TABLE III Cholecystokinin plasma values in response to a standard liquid test meal in gall stone patients and controls

\begin{tabular}{|c|c|c|c|c|}
\hline & \multicolumn{3}{|c|}{ Gall stone patients } & \multirow[b]{2}{*}{$\begin{array}{l}\text { Controls } \\
n=19\end{array}$} \\
\hline & $\begin{array}{l}\text { Normal } \\
\text { contractors } \\
n=43\end{array}$ & $\begin{array}{l}\text { Pathological } \\
\text { contractors } \\
n=13\end{array}$ & $\begin{array}{l}A l l \\
n=56\end{array}$ & \\
\hline $\begin{array}{l}\mathrm{CCK}_{\max }(\mathrm{pM}) \\
\mathrm{CCK}_{\max }(\mathrm{pM}) \\
\mathrm{CCK}_{-A U C}(\mathrm{pM} \times 90 \mathrm{~min})\end{array}$ & $\begin{array}{l}0 \cdot 8(0 \cdot 1) \\
5 \cdot 8(0 \cdot 4) \\
221(13)\end{array}$ & $\begin{array}{l}0.8(0 \cdot 1) \\
5 \cdot 5(0 \cdot 4) \\
242(30)\end{array}$ & $\begin{array}{l}0 \cdot 8(0 \cdot 1) \\
5 \cdot 7(0 \cdot 5) \\
226(12)\end{array}$ & $\begin{array}{l}0 \cdot 8(0 \cdot 1) \\
5 \cdot 1(0 \cdot 5) \\
184(14)\end{array}$ \\
\hline
\end{tabular}

$\mathrm{CCK}_{\mathrm{ma}}=$ basal CCK concentration, $\mathrm{CCK}_{\max }=$ maximal $\mathrm{CCK}$ concentration, $\mathrm{CCK}-\mathrm{AUC}=$ area under the CCK-CCK concentration/time curve for 90 minutes. No significant differences were obtained between any groups with regard to any given parameter. Mean (SEM). enhanced ejection volume in normal contractors is unlikely to result from diminished outflow resistance.

Comparing postprandial CCK release in gall stone patients with and without impaired gall bladder emptying and healthy subjects no significant differences were obtained. These results show that changes in gall bladder motor function in gall stone patients are not associated with a modification of CCK secretion. Based on acute experiments it was proposed that bile influx into the duodenum may inhibit stimulated CCK secretion. ${ }^{38}$ Consequently, non-contractor patients should secrete more CCK postprandially than normal contractor patients. ${ }^{1920}$ Our data suggest, however, that in a chronic steady state of impaired gall bladder emptying such a phenomenon is not found or is at least overcome by adaptive mechanisms. Accordingly stimulated CCK plasma values are neither changed several weeks after cholecystectomy ${ }^{39}$ nor do they differ between patients with chronic bile duct obstruction and healthy controls. ${ }^{40}$

We conclude, that in normal postprandial gall bladder emptying, ejection volume and residual volume are closely correlated with fasting volume. Thus, fasting volume seems to be an essential factor affecting physiological gall bladder motility. Differences in fasting volume between groups will therefore require special consideration in future studies evaluating gall bladder emptying. In gall stone patients two different mechanisms, an insufficient physiological mechanism to cope with larger gall bladder volumes in normal contractor patients and an impaired gall bladder muscle function in pathological contractor patients, led to nearly a $50 \%$ increase in mean postprandial residual volume.

1 Hay DW, Carey MC. Pathophysiology and pathogenesis of cholesterol gallstone formation. Semin Liver Dis 1990; 10: 159-70.

2 Roslyn JJ, Pitt HA, Man LL, Ament ME, DenBesten L. Gallbladder disease in patients on longterm parentera nutrition. Gastroenterology 1983; 84: 148-54.

3 Everson GT, McKinley C, Lawson M, Johnson M, Kern F. Gallbladder function in human females: effect of the ovulatory cycles, pregnancy and contraceptive steroids. Gastroentory cycles, pregnancy and

4 Krejs GJ, Orci L, Conlon JM, Ravazzola M, Davis GR, Raskin $\mathrm{P}$, et al. Somatostatinoma syndrome. Biochemical, morphological and clinical features. $N$ Engl $\mathcal{f}$ Med 1979; 301 285-92.

5 Gordon P, Comi RJ, Maton PN, Go VLW. Somatostatin and somatostatin analog (SMS 201-995) in the treatment of hormone-secreting tumors of the pituitary and gastrointestinal tract and non-neoplastic diseases of the gut Ann Intern Med 1989; 110: 35-50.

6 Shaffer EA, McOrmand P, Duggan H. Quantitative cholescintigraphy: assessment of gallbladder filling and emptying and duodenogastric reflux. Gastroenterology 1980; 79: 899-906. 
7 Fisher RS, Stelzer F, Rock E, Malmud LS. Abnormal gallbladder emptying in patients with gallstones. Dig Dis Sci 1982; 27: 1019-24

8 Forgacs IC, Maisey MN, Murphy GM, Dowling RH. Influence of gallstones and ursodeoxycholic acid therapy on gallbladder emptying. Gastroenterology 1984; 87: 299-307.

9 Festi D, Frabboni R, Bazzoli F, Sangermano A, Ronchi M, Rossi L, et al. Gallbladder motility in cholesterol gallstone
disease, Gastroenterology 1990; 99: 1779-85.

0 Masclee AAM, Jansen JBMJ, Driessen WWM, Geuskens LM, Lamers CBHW. Plasma cholecystokinin and gallbladder response to intraduodenal fat in gallstone patients. bladder response to intraduode
Dig Dis Sci 1989; 34: 353-9.

11 Kinshk SMA, Darweesh RMA, Dodds WJ, Lawson TL, Stewart ET, Kern MK, et al. Sonographic evaluation of resting gallbladder volume and postprandial emptying in patients with gallstones. $A \mathcal{F} R$ 1987; 148: 875-80.

12 Spengler U, Sackmann M, Sauerbruch T, Holl J, Paumgartner G. Gallbladder motility before and after extracorporeal shockwave lithotripsy. Gastroenterology 1989; 96: 860-3

13 Krishnamurthy GT, Bobba VR, McConnell D, Turner F, Meszgarzadeh M, Kingston E. Quantitative biliary dynamics: introduction of a noninvasive scintigraphy technique. 7 Nucl Med 1983; 24: 217-23.

14 Pomeranz IS, Shaffer EA. Abnormal gallbladder emptying in a subgroup of patients with gallstones. Gastroenterology 1985; 88: 787-91.

15 Van Berge Henegouwen GP, Hofmann AF. Nocturnal gallbladder storage and emptying in gallstone patients and healthy subjects Gastroenterolo $1978 ; 75: 879-85$.

16 Northfield TC, Hofmann AF. Biliary output during three meals and overnight fast. Relationship to bile acid pool size and cholesterol saturation of bile in gallstone patients and control subjects. Gut 1975; 16: 1-11.

17 Mok HYI, von Bergmann K, Grundy SM. Kinetics of the enterohepatic circulation during fasting: biliary lipid secretion and gallbladder storage. Gastroenterology $1980 ; 78$. 1023-33.

18 Maugdal DP, Kupfer RM, Zentler-Munro PL, Northfield TC. Postprandial gallbladder emptying in patients with gallstones. BMF 1980;1: 141-3.

19 Van Erpecum KJ, van Berge Henegouwen GP, Stolk MFJ, Hopman WPM, Jansen JBMJ, Lamers CBHW. Fasting
gallbladder volume, postprandial emptying and cholegallbladder volume, postprandial emptying and chole-
cystokinin release in gallstone patients and normal subjects. cystokinin release in gallstone

20 Thompson JC, Fried GM, Ogden WD, Fagan FJ, Inoue K, Weiner I, et al. Correlation between release of cholecystokinin and contraction of the gallbladder in patients with gallstones. Ann Surg 1982; 195: 670-6.

21 Everson GT, Braverman DZ, Johnson ML, Kern F Jr. A critical evaluation of real time ultrasound for the study of gallbladder volume and contraction. Gastroenterology 1980; 79: $40-6$.

22 Nusted R, Köhler H, Fölsch U, Schafmayer A. Plasma concentrations of neurotensin and CCK in patients with concentrations of neurotensin and CCK in patients with
chronic pancreatitis with and without enzyme substitution. Pancreas 1991; 6: 260-5.

23 Vezina WC, Paradis RL, Grace MD, Zimmer RA, Lamont $\mathrm{DD}$, Rycroft $\mathrm{M}$, et al. Increased volume and decreased emptying of the gallbladder in large (morbidly obese, tal normal and muscular normal) people. Gastroenterology 1990 98: $1000-7$

24 Kraglund K, Hjermind J, Jensen FT, Stodkilde-Jorgensen H Oster-Jorgensen E, Pedersen SA. Gallbladder emptying and gastrointestinal cyclic motor activity in humans. Scand F Gastroenterol 1984; 19: 990-4.

25 Van Erpecum KJ, van Berge Henegouwen GP, Stolk MFJ, Hopman WPM, Jansen JBMJ, Lamers CBHW. Effects of ursodeoxycholic acid on gallbladder contraction and cholecystokinin release in gallstone patients and normal subjects. Gastroenterology 1990; 99: 836-42.

26 Howard P, Murphy GM, Dowling RH. Effects of chenodeoxycholic and ursocholic acids on gallbladder emptying. Gut 1985; 26: A1124.

27 Niederau C, Heintges T, Rovati L, Strohmeyer G. Effects of loxiglumide on gallbladder emptying in healthy volunteers Gastroenterology 1989; 97: 1331-6.

28 Walker JP, Khalil T, Wiener I, Fagan CJ, Townsedd CM Jr, Greeley $\mathrm{GH} \mathrm{Jr}$, et al. The role of neurotensin in human gallbladder motility. Ann Surg 1985; 201: 678-83.

29 Marzio L, Capone F, Neri M, DiFelice F, Celiberti V, Mezzetti A, et al. Effect of cholinergic agonists and antagonists on gallbladder volume in fasting man. Eur Clin Pharmacol 1987; 33: 151-3.

30 Parkin GJS, Smith RD, Johnston D. Gallbladder volume and contractility after truncal selective and highly selective contractility after truncal selective and highly selective

31 Behar J, Lee KY, Thompson WR, Biancani P. Gallbladder contraction in patients with pigment and cholesterol stones. Gastroenterology 1989; 97: 1479-84.

32 Patterson SW, Piper H, Starling EH. The regulation of the heart beat. $\mathcal{F}$ Physiol 1914; 48: 465-513.

33 Gabella G. Structure of muscles and nerves in the gastrointestinal tract. In: Johnson LR, ed: Physiology of the gastrointestinal tract. New York: Raven Press, 1989: 335-83.

34 Ryan J, Cohen S. Gallbladder pressure-volume response to gastrointestinal hormones. Am 7 Physiol 1976; 230: 1461-5.

35 Washabau RJ, Wang MB, Dorst CL, Ryan JP. Effect of muscle length on isometric stress and myosin light chain phosphorylation in gallbladder smooth muscle. Am 7 Physio 1991; 260: G920-4.

36 Bouchier IA, Cooperband SR, El Kodsi BM. Mucus substances and viscosity of normal and pathological human bile. Gastroenterology 1965; 49: 343-53.

37 Csendes A, Kruse A, Funch-Jensen M, Oster MJ, Ornsholt J Amdrup E. Pressure measurements in the biliary and pancreatic duct system in controls and patients with gallstones, previous cholecystectomy, or common bile duct stones. Gastroenterology 1979; 77: 1203-10.

38 Gomez G, Upp JR, Louis F, Alexander RW, Poston GJ, Greeley GH, et al. Regulation of cholecystokinin bile salts in dogs and humans. Gastroenterology 1988; 94: 1036-46.

39 Gelin J, Rehfeld JF, Jansson R, Svanvik J. The secretion of cholecystokinin in the gallstone patient before and after removal of a functioning gallbladder. Surgery 1987; 101: $201-4$.

40 Koop I, Koop H, Gerhardt C, Schafmayer A, Arnold R. Do bile acids exert a negative feedback control of cholecystokinin? Scand f Gastroenterol 1989; 24: 315-20. 